\title{
Heroism Science
}

Volume 5

Issue 2 Special Issue - The Downside of

Heroism

Article 1

2020

\section{Ethical Concerns of Heroism Training}

Brian R. Riches

Claremont Graduate University, brian.riches@cgu.edu

Matt Langdon

Hero Construction Company, matt@heroroundtable.com

Ari Kohen

University of Nebraska-Lincoln, akohen2@unl.edu

Follow this and additional works at: https://scholarship.richmond.edu/heroism-science

Part of the Leadership Studies Commons, and the Psychology Commons

\section{Recommended Citation}

Riches, Brian R.; Langdon, Matt; and Kohen, Ari (2020) "Ethical Concerns of Heroism Training," Heroism Science: Vol. 5 : Iss. 2 , Article 1.

DOI: $10.26736 / \mathrm{hs} .2020 .02 .01$

Available at: https://scholarship.richmond.edu/heroism-science/vol5/iss2/1

This Article is brought to you for free and open access by UR Scholarship Repository. It has been accepted for inclusion in Heroism Science by an authorized editor of UR Scholarship Repository. For more information, please contact scholarshiprepository@richmond.edu. 
Heroism Science: An Interdisciplinary Journal (ISSN 2573 -

7120) https://scholarship.richmond.edu/heroism-science/

Vol. 5 No. 2 (2020) pp. 1-25

\section{Ethical Concerns of Heroism Training}

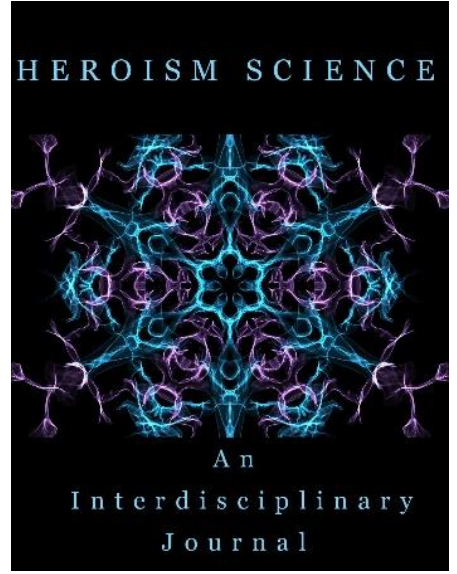

\section{BRIAN R. RICHES ${ }^{1}$}

Claremont Graduate University

brian.riches@cgu.edu

\section{MATT LANGDON}

Hero Construction Company

ARI KOHEN

University of Nebraska-Lincoln

Send correspondence to Brian R. Riches, Division of Behavioral and Organizational Sciences, Claremont Graduate University, ACB 124, 150 E. 10th Street, Claremont, CA 91711,.USA.Email: brian.riches@cgu.edu

KEYWORDS: heroism training, risk assessment, mortality assessment, domain-specific training, ethics with minors

\section{Article history}

Received: August 15, 2019

Received in revised form: September 20, 2019

Accepted: November 25, 2019

Available online: February 22, 2020

\footnotetext{
${ }^{1}$ Copyright 2020 Heroism Science ISSN: $2573-7120$ | Licensed under the Creative Commons, AttributionNonCommercial-NoDerivs (CC By-NC-ND)
} 
ABSTRACT: Heroism training programs originated in the mid-2000s with the goal to "Train everyday heroes" (Heroic Imagination Project, 2017). Most participants of these programs are students between the ages of 10 and 20. Anecdotal and empirical evidence suggests that these programs may create more courageous and prosocial people (Heiner, 2018; Kohen \& Sólo, 2019), however there is very little discussion in the emerging academic field of heroism science about the potential ethical concerns of training minors to be heroes (Beggan, 2019; Franco \& Zimbardo, 2016; Franco et al., 2017). With the growth of heroism science scholarship, it would be wise to examine and offer best practices for the ethical training of heroism with minors.

Heroic action is inherently risky, and while training programs currently discuss mortality and risk assessment, minors have not developed the neural or cognitive capacity to assess risks as adults can. Furthermore, the content and goals of heroism training may go against schools' and parents' wishes. Heroism training programs also have the potential to make heroism seem glamorous, which could lead some participants to seek out, or create, situations requiring heroic action. The paper discusses these, and other, ethical concerns in training minors to be heroes. The paper concludes with a variety of best practice recommendations for heroism training programs working with minors including; obtaining parent consent for training, working to improve minors' risk assessment abilities, domain specific training, and involving parents and other relevant stakeholders in the heroism training process. 


\section{INTRODUCTION}

Heroism is choosing to act in situations that present a significant risk to the actor's physical, mental, social, or economic wellbeing; additionally, this risky action must be done to benefit others rather than solely for one's own good. The two critical components of this definition are first, that heroism is risky, and second, that it is done to benefit others. At times heroism has been called altruism plus risk (Franco \& Zimbardo, 2016). There is conceptual overlap between heroism and altruism, but while altruistic actions may pose very little risk to the actor the minimum standard of risk for a behavior to be considered heroism is much higher (Franco et al., 2011). Further, empirical evidence suggests that helping in a high-risk situation is qualitatively different than more general helping that might be defined as altruism (Greitemeyer, Fischer, Kastenmüller, \& Frey, 2006). Heroic actions can have a dramatic positive impact on individuals rescued by heroes, or people affected by the situations heroes work to change. To encourage more of this type of behavior, heroism training programs have emerged with the goal to "train everyday heroes" (Heroic Imagination Project, 2017). Most participants of these programs are students between the ages of 10 and 20. Anecdotal and empirical evidence suggests that these programs may create more courageous and prosocial people (Heiner, 2018; Kohen \& Sólo, 2019), however there is very little discussion in the emerging academic field of heroism science about the potential ethical concerns of training minors to take heroic action (Beggan, 2019; Franco \& Zimbardo, 2016; Franco et al., 2017). With the growth of heroism science scholarship it would be wise to examine and offer best practices for the ethical heroism training of minors.

Heroism trainers want to create more prosocial people who are prepared to act heroically when a situation arises that requires heroic intervention. A number of organizations have been providing heroism training consistently over more than ten years. These trainings can be divided into two approaches: indirect and direct. The indirect approach 
was the first to be used and involves using examples from real life to provoke questions of how the heroes were able to act, why they acted, and what can be learned. This approach inspires thinking about what the student could do and aims to provide examples a student could recall in a situation requiring heroism. In this way the indirect approach might indirectly increase heroic behavior. The best of these efforts include lesson plans or resources to unpack the stories. For example, the Giraffe Heroes Project provides hundreds of profiles searchable by various categories. The examples are nominated and approved by a small group and the entire database is accompanied by teacher guides, student surveys, and other learning and training material. Their programming starts with grades K-2 and goes up to materials that are relevant for teenagers. Similarly, the Lowell Milken Center for Unsung Heroes promotes project-based learning around heroic individuals alongside a physical museum featuring hero exhibits. The group encourages, and supports, students to create public-facing projects about unsung heroes from history. The programs are aimed at grades 6-12.

By contrast, the direct approach focuses on teaching the science and practices important to heroic action to the students directly. These programs tend to focus on awareness of social psychology research, situational awareness, and risk assessment. This approach aims to give tools and practices to students in order to prepare them for direct action in potential heroism situations. They also emphasise the power of individual and collective action, and the development of courage. The Heroic Imagination Project, founded by Philip Zimbardo, delivers programs to young adults through in-person, trainer-led workshops in many countries around the world. They focus on teaching bystander intervention, growth mindset, and an introduction to heroism. In a similar vein is the Hero Construction Company, which works mostly with grades 3-9. The Hero Construction Company focuses on in-person, trainer-led assemblies and classroom workshops. There are also free lesson plans available for teachers and parents to download and deliver on their own (Kohen \& Sólo, 2019). The 
organization has a broad approach, including social psychology, comparative literature, bystander intervention, and the provision of heroic exemplars. Early classroom work by the Hero Construction Company was shown to increase student levels of courage on a self-report scale for up to a month after the training (Heiner, 2018).

The goal of heroism education is to make students more likely to act heroically. This includes promoting agency and providing permission to use that agency, increasing awareness of psychological and social barriers to acting on behalf of others, sharing stories of heroic action, and teaching skills and habits that increase the chances of overcoming the barriers to action. As we have argued elsewhere, students thus trained will be more likely to get involved in preventing bullying, reducing vandalism, standing up to intolerance and injustice, and proactively creating a positive school environment (Kohen, Langdon, \& Riches, 2019).

A central concept that must be brought to the fore in any discussion with people - and especially young people_-about taking heroic action is the connection between heroism and risk. There are many ways to act pro-socially without taking risk but when one reaches the threshold that separates altruism from heroism, danger plays a crucial role. When taking heroic action, heroes are confronted with risk-taking that goes beyond losing a small amount of time, money, or even social prestige. Heroes, after all, are those who charge into burning buildings to rescue others, run toward the sound of gunfire or tackle a gunman, leave their cars by the side of a busy highway to assist injured motorists, attempt to deescalate conflict by physically interposing themselves between rivals, and break rules or even laws to blow the whistle on corporate or government malfeasance. Time and time again, they put themselves directly in harm's way to help others.

Why do these people take such risky heroic action? Research suggests two important factors: because they've been trained to respond and because no one else can or will do it 
(Kohen, Langdon, \& Riches, 2019). If we are training people to take action in situations such as these, it is incumbent upon us to share the attendant difficulties and dangers, and to work with young people on improving their ability to assess risk. Heroic behavior is required for situations in which pretty much everything has gone wrong. If a building is on the verge of collapse, people are trapped inside, and firefighters have been ordered not to go back inside, it is the hero who defies the order and attempts one more rescue. If a government's laws, policies, and practices harm a group of people, it is the whistleblower who breaks those laws even as doing so puts them in legal jeopardy. In these cases, there is no one else to whom we can turn, no better expert or higher authority for whom a person can wait.

Heroes cannot escape these risks; risk-taking is a core component of heroic action. As such there could be ethical concerns with training people, especially minors, to act heroically (Beggan, 2019). Most of these concerns are related to the principles of beneficence and nonmaleficence. When heroism training first began, the people who produced these curricular materials and organized these training materials sought to benefit society by changing the way individuals understood what they could or should do on behalf of others and, more broadly, their communities. But we maintain that heroism trainers also must seek to benefit the people with whom they work and must work diligently to avoid harm to people.

Additionally, heroism trainers should seek to improve contexts, such as school communities, and seek to avoid harm to contexts. In thinking about the ethical obligations of trainers and researchers, it is paramount to focus on the inherent dignity and worth of every individual and to treat all persons, to use Immanuel Kant's terminology from the Grounding of the Metaphysics of Morals, as ends in themselves rather than as means to an end. While not all heroism trainers are psychologists, and not all training materials come from psychological research, the field of heroism science was born from psychology and we believe that heroism trainers should follow applicable components of the American Psychological Association's 
Ethical Principles of Psychologists and Code of Conduct. Working to benefit others and avoiding harm to participants in training programs is essential not only because it is the moral thing to do, but also because following these standards will help the field retain respect, and grow to reach other people to further benefit humanity.

This paper will review the potential ethical concerns of training minors to act heroically, including minors' lack of cognitive capacity to evaluate risk as compared to adults, the fact that heroism training may go against the wishes of parents, guardians, or school administrations, heroism training may make heroic actions seem too easy and glamorous, and the potential negative self-concept and emotional experiences that young people could have when realizing they have not acted heroically. At the outset of discussing these ethical concerns, we want to clarify that while there may be ethical concerns with heroism training, we are not recommending that it should be abandoned. We see heroism training as beneficial to society, but it must be weighed against the possible costs to the individuals being trained, especially if those people are minors. After presenting all ethical concerns we offer best practices and potential solutions to help heroism trainers mitigate these potential ethical concerns, while continuing to work to build more heroic individuals.

\section{Potential Ethical Concerns of HeRoIsm TRAining}

\subsection{MINOR'S ABILITY TO ASSESS RISKS}

While there seems to be great interest in developing effective heroism training programs, at this point the heroism science literature contains very little discussion about the potential ethical concerns of training minors to be heroes (Franco \& Zimbardo, 2016; Franco et al., 2017). Some of the potential ethical concerns extend to adults as well as minors, but the ethical concerns that are potentially most problematic exist with regard to minors. The first, and possibly most important, potential ethical concern facing heroism training for minors is 
that training might make young people more likely to put themselves at great risk because they have not yet developed the cognitive capacity for risk assessment that adults have. Many cognitive abilities are tied to the physical development of the brain. With regard to neural development, the amygdala develops early on in adolescence (Smith, Chein, \& Steinberg, 2013; Steinberg, 2012, 2015). The amygdala is a part of the human brain's limbic system, and is the neural control center for emotion (Smith, Chein, \& Steinberg, 2013; Steinberg, 2012). The prefrontal cortex, which is responsible for long-term planning and self-regulation, does not finish its development through pruning and myelination until closer to age 25 (Steinberg, 2015). In practical language, this means that in early adolescence the emotion center of the human brain is fully formed, adolescents are feeling a wider range of, and stronger, emotions than at any time previously in their lives (Nelson, 2003; Steinberg, 2012). Additionally, these adolescent brains have not fully developed the physical structures between the prefrontal cortex and amygdala that are necessary for the emotional control adults are capable of (Nelson, 2003), which in turn leads to increased risk-taking behavior (Steinberg, 2015). This means that before the age of about 25, children, adolescents, and even young adults are not neurologically capable of assessing risks in the same way as adults.

These neurological and cognitive components of development are problematic for heroism training because heroic actions are risky. When heroism trainers encourage heroic action from children and adolescents it may lead to increased risk-taking behavior, or attempted heroism where an adult with the capacity to properly evaluate the risk of a situation would not act. This leads to the serious question, should we in the field of heroism science encourage minors to take risky action? As heroism trainers, we are responsible for the content we deliver, and we should be held at least partially responsible for the actions taken by minors in response to our heroism training programs (Beggan, 2019). We do not want young people risking, or losing, their lives in situations that are well beyond their capacity to act. 
However, these risks can be mitigated through practices that heroism trainers can implement; we will cover these best practices after presenting all the potential ethical concerns and questions related to this risk assessment problem.

\subsection{ETHICAL QUESTIONS}

It is clear that adolescents cannot assess risks in the same way as adults, which brings up additional questions. One important question for heroism trainers is, how should we talk to adolescents about their own mortality? Should heroism trainers emphasize the potential for mortal danger when discussing heroism with minors in an effort to help them assess the risks of heroism more accurately? The goal of heroism training is to encourage risky action for the good of others, so we do not want to scare trainees away from taking any action. However, we also do not want to harm these trainees. How can heroism trainers find a balance between helping adolescents make more accurate risk assessments while encouraging inherently risky heroic action? Additionally, heroism trainers often use examples to help people see what heroism might look like for people in their age group and context. Related to the risk assessment of adolescents, and concerns over their mortality, which situations should heroism trainers be using to encourage heroism in minors? Should heroism trainers also use examples of young people saving others from incredibly dangerous situations such as rescuing someone from a burning building or fast moving river?

Training minors to act heroically has the potential to be ethically problematic; we have proposed several crucial questions related to these ethical concerns. At this point it is essential that we qualify these concerns with a reminder that adolescent risk-taking is affected by numerous contextual factors such as the adolescent's peer group, parents, and community supports rather than biology and neurology exclusively (Steinberg, 2015). Heroism training can involve parents, peers, and school contexts which could help minors understand and 
develop better risk assessment skills. We expound on this idea and discuss best practices that can help facilitate these positive contexts, and minimize the potential problems of training minors to act heroically beginning at the midpoint of this paper. For now, we turn to our next potential ethical problem, a discussion of the ethical concerns parents and school administrators might have.

\subsection{ETHICAL CONCERNS OF PARENTS AND SCHOOL AdMINISTRATORS}

The primary potential ethical concerns of parents and school personnel is that heroism training may be encouraging minors to act in ways with which their authority figures do not agree with, and put their children at risk of harm. Three examples may illustrate the first problem. One common training example for children and adolescents is that of standing up to bullying. One suggestion heroism trainers might give the students is to stick their neck out and confront bullying, but parents and teachers might prefer that they avoid this tactic. Similarly, students might be encouraged by heroism trainers to call out, and work to stop, injustice, but school staff and administration might prefer that students not take action into their own hands. The last example is that students are often encouraged to step out of their comfort zone by heroism trainers. By doing something uncomfortable, such as wearing bright orange pants, participants prepare for the discomfort of a situation arising that requires heroic action. In these examples, the training provided may be counter to the desires of parents and school administration. Parents and school administration might prefer that students use established systems to address problems, rather than taking direct action. Should heroism trainers encourage minors to act even when those actions might be against the wishes of the authorities and hierarchies that are in place around the minors? This is an especially important question to answer because we know from decades of research on character education that programs are most effective when the behaviors are modeled by parents and 
teachers (Berkowitz \& Bier, 2005). If parents and teachers do not agree with the material being presented it may have less of an impact. Additionally, the programs may not be used by parents and schools if they are in disagreement with the suggestions.

The second related concern of parents and school administration is the potential risk of harm to minors. It is understandable that parents and administrators want to keep minors safe, and specifically protected from the risks inherent in heroism. Heroism trainers do want to prepare people to take prosocial action, and sometimes those prosocial actions are heroic and risky. It might seem these goals are opposed, but as discussed in the beginning of this paper, heroism trainers are also concerned about young people taking risks that should be avoided (Beggan, 2019). One common concern heard from young people is that if they stand up to bullying they might become a target of bullying, or they could get hurt. Heroism trainers are also concerned about young people who are unable to properly assess risks taking dangerous action in response to our training. These are real ethical concerns that should not be minimized or ignored. One possible suggestion to mitigate the potential ethical concern of training minors to act in ways that are against their parents' and school administrators' wishes is to provide a wide range of example actions for minors to take in any given situation. This idea will be discussed in more detail in a future section.

\subsection{Potential Ethical Problems Caused by Heroism Training}

All of the ethical problems we have discussed at this point are indirectly caused by heroism training; young people do not have the neural or cognitive capacity to assess risks as adults do, and parents and teachers may be concerned with various aspects of heroism training. The following potential ethical concerns are directly caused by heroism training. These include the potential for heroism trainers to make heroism seem glamorous, as well as causing trainees to feel shame or symptoms of depression because of past or present inaction. 
From the beginning of recorded history heroes have been seen as exemplars of human achievement, forces for the social good, and role models to be emulated (Franco et al., 2017; Kohen, 2013). It is unsurprising that heroism trainers use heroes as examples to motivate prosocial and heroic action. However, in an effort to encourage heroic behavior from trainees we may be making heroism seem too glamorous. This perception of heroism being glamorous, along with minors being unable to assess risks as well as adults, could lead some minors to go out of their way to look for situations in which to act heroically, or to put themselves in scenarios where heroism might be necessary. There are anecdotal examples of people being inspired by superhero stories taking to the streets as vigilantes (Oppmann, 2011). There is even a martial arts school that focuses on training people to be superheroes, encouraging good deeds, altruism, self-defense, weapons training, and physical preparation to enable rescue if a situation calls for it (Reed, 2017). However, these anecdotal examples are few and far between. It seems that seeking out heroism is not very common, but if only one out of 500 minor trainees actively seeks out situations to act heroically in, it is a concern.

Related to the concern that some young people may seek out situations in which to act heroically is the problem that some minor trainees might even seek to create situations where they can act "heroically," actively putting people in danger to have the opportunity to act heroically, or to appear to act heroically. This process is similar in some ways to Munchausen syndrome by proxy, where a caretaker may cause medical symptoms in a child, or make it appear the child has symptoms, which results in unnecessary medical procedures (Meadow, 1982). This concern clearly overlaps with the problem of minors not being able to assess risks as adults can, as well as the fact that their cognitive ability to plan complex behavior is not yet fully developed. In summary, heroes, even superheroes, can be great examples to encourage prosocial behavior (Allison \& Goethals, 2011; Steinberg, 2017), but how can 
heroism trainers combat the potential for minor trainees to actively seeking out, and possibly even create, situations where heroism is needed?

Heroism training also has the potential to cause trainees to feel shame or symptoms of depression because of past or present inaction. As an example, one trainee related a story that when she was working at a fast food restaurant at about 16 years of age, she witnessed her manager stealing money during the nightly count. She expressed that she did not know what to do in that situation, and heroism training could have helped her act. While this participant was excited to learn about how she could have behaved, she could have had the opposite reaction. She could have felt uncomfortable, guilty, shamed, or even symptoms of anxiety or depression when realizing there were actions she could have taken, but did not. While guilt can be a motivating moral emotion, leading people to right their wrongs, shame is a moral emotion that leads people to retreat and avoid the problem, people they have hurt, and avoid seeking to create solutions (Haidt, 2003). Shame is a painful emotion people feel when they believe they are flawed or defective, but take no steps to remedy the situation (Haidt, 2003). This kind of response is not what heroism trainers are aiming to produce. Similarly, depression and symptoms of depression such as apathy, defiant behavior, sadness, lack of effort, and anxiety can be very harmful to children and adolescents (Mehler-Wex \& Kölch, $\underline{2008)}$, and should be avoided. These responses can be especially serious for any young person who already has low self-esteem, does not feel they have self-efficacy, or may be suffering from clinical depression. How can heroism training mitigate or avoid the potential ethical problem of instilling painful emotions such as shame and depression in trainees? In the following section we discuss potential answers to these questions. 


\section{Suggestions of Best Practices in Heroism Training}

In the previous section we explored the potential ethical concerns related to, and caused by, heroism training. In this section we will discuss possible answers to these concerns and recommend best practices to minimize these concerns and problems. The primary suggestions are that heroism training should work to improve minors' risk assessment ability, include a variety of heroism example scenarios, incorporate domain specific training, work to receive parental consent for training, and involve parents and stakeholders in the heroism training process. These recommendations will not eliminate all ethical concerns of heroism training, but they will minimize these concerns.

\subsection{IMPROVING MINORS' RISK ASSESSMENT}

To protect against the ethical problem of adolescents being unable to assess risks as adults can, heroism training programs can incorporate training to improve minors' risk assessment abilities. Researchers have found the opportunity to practice realistic decisionmaking through role-playing, group discussion, and group problem-solving can increase adolescent risk assessment (Compas \& Reeslund, 2009). These role-plays, group discussions, and group problem-solving sessions could be incorporated into heroism training by using heroic situations. Many heroism training programs already use role-plays and group discussions so including or incorporating many realistic situations and a variety of potential actions for trainees to discuss and role-play is one way to improve minors' risk assessment abilities.

There are also large bodies of research and training programs related to risk assessment that could be incorporated into heroism training programs. Self-regulation, the ability to regulate emotions, attention, and behavior, helps decrease risk-taking, and increases the ability to assess risks by enabling a young person with greater self-regulation to attend to 
their emotional state and behavior more critically and effectively than others (Oettingen \& Gollwitzer, 2015). Heroism trainers could refer to programs such as the Zones of Regulation by Leah Kuypers or the Alert Program that focus on increasing adolescent self-regulation in different contexts. These programs help participants be more aware of their current state of alertness and emotional calmness, and how those states affect decision-making. Heroism training programs could also incorporate activities that work to increase impulse and selfcontrol (Diamond \& Lee, 2011; Duckworth \& Steinberg, 2015).

Additionally, positive school, parent, and community contexts can act as protective factors to child and adolescent risk-taking more generally (Resnick et al., 1997). While a single heroism training program would be unable to improve all relevant protective factors in school, community, and parent contexts, heroism training programs could choose which context on which they could have the greatest impact during that implementation of the program and focus on building that positive context.

A final point to consider is the importance of play in developing healthy risk-taking and improved risk assessment. While simulation and role-play can help, unstructured play is a key developmental process for children. Risky play for children helps them develop their risk assessment and cognitive analytical skills (Baker, 2019). "It reduces the likelihood of impulsive risk taking in adolescence, and it also helps children self-regulate socially and emotionally (Baker, 2019, p. 1)." Unstructured play for children that includes risks could be incorporated into relevant heroism training programs. These opportunities will support young people's ability to assess risk and increase self-regulation for future heroic action.

Using role-playing, risk assessment, self-regulation training, and involving parents, schools, and communities in heroism training to support young people's development, can protect against the concerns posed by minors' risk assessment abilities. Heroism training 
programs can incorporate training that already exists to improve minors' risk assessment abilities, or fashion their own for inclusion in their current programming.

\subsection{InClude Various Heroism Example Scenarios}

In an effort to minimize the ethical concerns of parents and school administration, and to reduce the concerns about discussing mortality with minors, we recommend heroism trainers use a wide variety of situations and potential actions in their examples and activities. First and foremost, any situations presented as examples should be relevant to the context of the heroism training participants; for example, a middle school student might be presented with a hero standing up to school bullying whereas an adult in a business setting might learn about whistleblowers. If student trainees live in a rural area, an example situation that happens on a subway could be difficult to apply to their own lives. We also recommend heroism training programs describe situations and potential actions with a wide range of risks. Along with this wide range of risk participants should be presented with numerous potential actions from those that are simply prosocial to actions that are heroic, including actions that represent minimal or no risk at all to those that represent extreme risk. Multiple options will help participants see there are multiple ways to act in any given situation, which will help reduce the risk of concern for their mortality and decrease the chance for anxiety. Additionally, understanding how to act in multiple situations will work to increase selfefficacy because participants believe they can take meaningful action, even if they may not choose a heroic action. Finally, including potential actions that are less risky in heroism training will help teachers, parents, and school administrators feel more comfortable with those options, and reduce their concerns.

We recommend sharing the reflections of heroes who describe their experiences. It is almost unheard of that a hero describes their actions as glamorous or exciting. For example, 
Katherine Bolkovac acted heroically as a whistleblower, lost her job, was nearly prosecuted for crimes, and encountered numerous challenges during and following her heroic actions but still said, "I'm dedicated to it. I feel like it's my social responsibility. I'm always going to be a cop at heart. I'm never going to make any money off of it. It's a labor of love and, to be honest, revenge. I'm a thorn in the side of DynCorp. I'm not going away (PeaceWomen, 2011)." Showing participants the unappealing nature of heroic action can help temper any thoughts of fabricating situations in which to perform heroic acts. It may also be important to note that very few heroes report regretting their heroism in order to avoid adding yet another barrier to action for potential future heroes.

What's more, it is necessary to point out that, all too often, heroes fail in accomplishing their prosocial aim and/or do not survive the attempt. There are many prominent examples of whistleblowers who lost their jobs or endured lengthy prison sentences, as well as much lesser-known examples of heroes who were injured or killed during attempts to help rescue drowning children or injured motorists. Kohen and Steinacher (2019) note that, in the quintessential example of heroic action, very few non-Jews rescued Jews during the Holocaust but we have only a rough estimate because some percentage of those who attempted rescue were caught and murdered. These are important facts that young people should be presented with as they progress through heroism training.

In addition to considering actions and situations that are relevant for the participant we recommend that heroism trainers seriously consider the level of risk they are encouraging minors to take. As an example, one author of this paper frequently uses the example of Wesley Autrey in his heroism training. Autrey rescued a man who suffered a seizure and fell onto subway tracks by covering the man with his own body as the train passed over them (Buckley, 2007). However, this author does not use this example when interacting with people younger than 14 because participants focused on the mortal risk rather than the lessons 
of taking action when others passively stood by. It is important for heroism trainers to consider the lessons they are trying to share with heroic examples; additionally, it may be more appropriate to teach very young participants to act in ways that are only prosocial, rather than to take actions that put them at serious risk. We also recommend that heroism trainers make it clear to participants that not everyone will encounter a situation in which to act heroically. If participants understand that not all people will encounter heroism, and that is expected and understandable, they may be less likely to seek out or create situations where heroic action is required.

Insofar as heroism training goes beyond educating students about heroism and crosses over into encouraging them to take heroic action on behalf of others, it seems clear that any ethical approach to such training must include a frank discussion of the risky nature of heroic behavior and possible avenues for mitigating some of that risk.

\subsection{INCORPORATE DOMAIN SPECIFIC TRAINING}

Another best practice for heroism training programs is to include domain specific training, such as swimming, first aid, CPR, or martial arts training, as part of the programming. Short of incorporating the training directly into their programs, heroism trainers could recommend domain specific training. Anecdotal evidence of Carnegie Heroes shows that many heroes awarded the Carnegie Medal for Acts of Civilian Heroism had special skills relevant to the situation in which they intervened, such as swimming, CPR, or martial arts training. Additionally, a few studies have found that the bystander effect is weaker, or does not occur, for people with domain specific training, or training to recognize the bystander effect itself (Fischer et al., 2011), which is something heroism training programs strive for. Additional evidence shows that in physical heroism situations, such as stopping a robbery or assault, people who were larger in stature and had completed rescue 
training were more likely to intervene (Huston, Ruggiero, Conner, \& Geis, 1981). It appears that practicing specific skills relevant to heroic actions may make people more likely to act. Heroism training programs could include modules on domain specific training, such as a unit on first aid, or simply encourage minor trainees to seek out this sort of training. In addition to increasing the possibility that those trainees will act heroically, domain specific training can have other positive effects such as increased physical fitness, increased self-efficacy, and a better understanding of how to respond during a crisis. Parents, teachers, and school administrators also likely have an understanding of and respect for domain specific training which may reduce their ethical concerns, and make them more likely to consent to having the minors under their charge participate in heroism training programs.

\subsection{Parental Informed CONSENT}

While some of the suggestions we have made will help reduce or eliminate the concerns parents may have over heroism training, those ethical concerns may still exist. Our strongest recommendation is that all heroism training with minors be done with the informed consent of parents or guardians. Heroism trainers often default to schools for the consent to provide training for students, but due to the potential ethical concerns of heroism training with minors we recommend this practice be avoided in favor of informed consent from parents and guardians directly. The American Psychological Association's Ethics Code (2017) states that

\footnotetext{
"When psychologists conduct research or provide assessment, therapy, counseling, or consulting services in person or via electronic transmission or other forms of communication, they obtain the informed consent of the individual or individuals using language that is reasonably understandable to that person or persons except
} 
when conducting such activities without consent is mandated by law or governmental regulation or as otherwise provided in this Ethics Code."

While heroism trainers may not be psychologists, it is likely that their training will be similar to what is referred to in the APA Ethics Code as consulting. Additionally, if trainers are evaluating their program and collecting data from participants, this constitutes research and would fall under the APA Ethics Code. These ethical standards were created to protect participants from harm as well as the trainers from potential legal problems, and as we discussed we do our work from the standpoint of benefiting others and avoiding harm. If we worry about the potential ethical concern that parents might not approve of heroism training, the only way to be reasonably sure they approve is by asking for their approval. Parents or guardians should be informed about

"(1) the purpose of the research (or training), expected duration, and procedures; (2) their right to decline to participate and to withdraw from the research once participation has begun; (3) the foreseeable consequences of declining or withdrawing; (4) reasonably foreseeable factors that may be expected to influence their willingness to participate such as potential risks, discomfort, or adverse effects; (5) any prospective research benefits; (6) limits of confidentiality; (7) incentives for participation; and (8) whom to contact for questions about the research and research participants' rights. They provide opportunity for the prospective participants to ask questions and receive answers (American Psychological Association, 2017).” Usually in research and treatment parents or guardians are given all relevant information on a single sheet of paper which enables them to inform themselves about, and consent to, their child's participation. We also recommend minor participants above the age of 10 be asked for their assent, and provided with similar information written in a way that is understandable to them. 
While heroism trainers may find these procedures to gather informed consent require more time and effort, and they might feel frustrated, we respond with empathy and solidarity. We understand these procedures may take more time, planning, and discussions back and forth with stakeholders and that can make accessing populations for heroism training on short notice more difficult. We also understand that these procedures are important to protect minor participants from potential harm. We recommend these procedures be planned when discussing with a school or other organization to ensure timely delivery and return of consent forms, whether digital or physical. Schools often have parent emails, and may send consent forms as a link or PDF in a mass email. It is also possible to give physical forms to teachers in the rooms where the training will happen at least a week in advance, and request they work to get the forms returned. Additionally, it may be possible to send both digital and physical consent forms for wider responses. Once consent forms have been received, we encourage heroism trainers and organizations to develop a secure and organized storage system. We strongly recommend heroism trainers obtain informed consent from the parents or guardians of minor trainees. Allowing parents the opportunity to give informed consent will minimize many of the ethical concerns we have discussed, as well as benefit any program that is in the process of testing or evaluating the efficacy of their program.

\subsection{INVOLVING PARENTS AND STAKEHOLDERS}

Our final recommendation will help reduce parents' concerns, extend the effects of heroism training, and potentially improve the contexts around the young people we train. We recommend involving parents, school teachers, school administration, and communities in the development and delivery of heroism training. This could include offering parents, teachers, and community members heroism training lessons. Researchers have shown that when it comes to character education, training parents helps them to reinforce the material at home 
(Berkowitz \& Bier, 2005). That is why experts in the field of character education recommend doing parent specific training and providing family reading materials or resources through websites that parents can access (Berkowitz \& Bier, 2005). Parents could also be trained to better communicate with their minor children about risk assessment. The more involved the parents, teachers, or community members are, the more reinforced and longer lasting the impact of the heroism training will be.

Working with parents, teachers, and community members could also include collaboration with these stakeholders by including them in the design and delivery of the program. Decades of evaluation research demonstrates that relevant stakeholders in young people's lives understand the local contexts, problems, risks, and protective factors better than we do as outside heroism trainers (Berkowitz \& Bier, 2005; Bryson, Patton, \& Bowman, 2011). Working with these stakeholders to tailor lessons, activities, and programming can improve relationships between heroism trainers and stakeholders, ensure we are using relevant examples, and help us see connections between our material and relevant situations in the schools and communities in which we conduct our trainings. Working with these stakeholders can also serve to decrease their ethical concerns, enable them to support the young people we train, and potentially lengthen the effects of heroism training.

\section{CONCLUSIONS}

Heroism trainers want to create more prosocial people who are prepared to act heroically when the situation calls for heroism. We believe heroism trainers want to, and should, follow the principles of beneficence and non-maleficence; as such, they should be concerned about the potential ethical problems of training minors to act heroically. While there are potential risks to training minors to act heroically, we want to be clear that we are not recommending heroism trainers avoid working with minors. On the contrary, evidence suggests, and we 
believe, that heroism training can be beneficial to individuals, including minors, as well as contexts such as their schools and communities. Minors who have a heroic imagination may have the ability and self-efficacy to make positive change in the people and environments around them throughout their lives. However, because these ethical concerns exist we recommend heroism trainers carefully consider our recommended best practices to minimize these potential ethical problems.

One additional consideration for heroism trainers is the threat of litigation in response to accidents or injury resulting from attempted heroic action by participants. This is particularly concerning in the United States. Purchasing liability insurance is one way to prepare for this and it would be surprising to learn of any teacher in any field operating without such coverage. Avoiding specific suggestions of heroic action could reduce the blame in a court case, but in today's world, it appears good lawyers are more important than good arguments. As suggested elsewhere, it is important for heroism trainers to stress the importance of risk-assessment to students. It is also wise for the teachers themselves to assess the risk of specific lessons, stories, and suggestions before delivering them. It could be argued that this risk of a lawsuit makes heroism trainers heroes themselves, but we would argue that the risk of being sued is so entrenched in every public act that it barely stands out. Operating a retail store, a summer camp, or a non-profit is just as risky. Finally, we have focused our discussion and recommendations on the potential ethical concerns of heroism training with minors, but there may also be ethical concerns of heroism training with adults. We believe that gaining informed consent of participants and using a wide variety of heroic situations may help ameliorate ethical concerns of heroism training with adults, but also recommend further research on how to reduce the potential ethical concerns of training adults to act heroically. 
We strongly recommend gaining informed consent from the parents and guardians of minors. Additionally, using a variety of potentially heroic situations with a wide variety of actions in examples and role-plays, and incorporating activities to improve adolescents' risk assessment abilities will help minimize the risk of harm to young people. In the end it is the decision of heroism trainers and organizations to implement any of the practices we have recommended. We only hope this paper shines some light on a few potential ethical concerns of heroism training, and starts the conversation about what heroism scientists can do to minimize these potential ethical problems.

\section{REFERENCES}

Allison, S. T., \& Goethals, G. R. (2011). Heroes: What they do and why we need them. Oxford University Press.

American Psychological Association. (2017). Ethical Principles of Psychologists and Code of Conduct. Retrieved from https://www.apa.org/ethics/code

Baker, J. (July 26, 2019). Really disastrous: the fragility epidemic that could change Australia. The Sydney Morning Herald, Retrieved from https://www.smh.com.au/education/really-disastrous-the-fragility-epidemic-that-couldchange-australia-20190726-p52b3j.html

Beggan, J. K., (2019). On the downside of heroism: Grey zone limitations on the value of social and physical risk heroism. Heroism Science, 4, 1-35.

Berkowitz, M. W., \& Bier, M. C. (2005). What works in character education: A researchdriven guide for educators. Washington, DC: Character Education Partnership. 
Bryson, J. M., Patton, M. Q., \& Bowman, R. A. (2011). Working with evaluation stakeholders: A rationale, step-wise approach and toolkit. Evaluation and program planning, 34(1), 1-12.

Buckley, C. (2007, Jan 3). Man is rescued by stranger on subway tracks. The New York Times. Retrieved from https://www.nytimes.com/2007/01/03/nyregion/03life.html

Compas, B. E. \& Reeslund, K. L. (2009). Processes of risk and resilience during adolescence. Handbook of adolescent psychology, 1 .

Diamond, A. \& Lee, K. (2011). Interventions shown to aid executive function development in children 4 to 12 years old. Science, 333(6045), 959-964.

Duckworth, A. L., \& Steinberg, L. (2015). Unpacking self-control. Child development perspectives, 9, 32-37.

Franco, Z. E., Allison, S. T., Kinsella, E. L., Kohen, A., Langdon, M. \& Zimbardo, P. G. (2017). Heroism Research: A Review of Theories, Methods, Challenges, and Trends. Journal of Humanistic Psychology, 58, 382-396. DOI: 10.1177/0022167816681232

Franco, Z. \& Zimbardo, P. (2016). The psychology of heroism: Extraordinary champions of humanity in an unforgiving world. The social psychology of good and evil, 494-523.

Greitemeyer, T., Fischer, P., Kastenmüller, A., \& Frey, D. (2006). Civil Courage and Helping Behavior. European Psychologist, 11, 90-98. doi:10.1027/1016-9040.11.2.90

Heiner, E. K. (2018). Fostering Heroism in Fourth- and Fifth-Grade Students. Journal of Humanistic Psychology, 002216781775399. https://doi.org/10.1177/0022167817753997

Heroic Imagination Project. (2017). Home page. Retrieved from https://www.heroicimagination.org/ 
Kohen, A. (2013). Untangling heroism: Classical philosophy and the concept of the hero. New

York: Routledge.

Kohen, A., Langdon, M., and Riches, B. R. (2019). The Making of a Hero: Cultivating Empathy, Altruism, and Heroic Imagination. Journal of Humanistic Psychology (59.4).

Kohen, A. and Sólo, A. (2019). Beyond the Campus: Heroism as a Case Study for Extending Researchers' Influence Through K-12 Lesson Plans. Heroism Science: An Interdisciplinary Journal (4.1).

Kohen, A. and Steinacher, G. J. (2019). Introduction. In A. Kohen and G. J. Steinacher (Eds.), Unlikely Heroes: The Place of Holocaust Rescuers in Research and Teaching. Lincoln, NE: University of Nebraska Press.

Meadow, R. (1982). Munchausen syndrome by proxy. Archives of disease in childhood, 57, 92-98.

Mehler-Wex, C., \& Kölch, M. (2008). Depression in children and adolescents. Deutsches Ärzteblatt International, 105, 149.

Nelson, C. A. (2003). Neural development and lifelong plasticity. In R. M. Lerner, F. Jacobs $\&$

D. Wertlieb (Eds.), Handbook of applied developmental science (Vol. 1). Thousand Oaks, CA: Sage.

Oettingen, G. \& Gollwitzer, P. M. (Eds.). (2015). Self-regulation in Adolescence. Cambridge University Press. 
Oppmann, P. (2011, November 24). Wannabe superhero won't face charges. CNN. Retrieved from https://www.cnn.com/2011/11/23/justice/washington-superherowannabe/index.html

PeaceWomen. (2011, October 17). International: Former Lincoln Cop Discusses Movie 'Whistleblower' Of Her Work With UN. Retrieved from https://www.peacewomen.org/content/international-former-lincoln-cop-discussesmovie-whistleblower-her-work-un

Reed, C. M. (2017, July 27). The superhero foundry teaches you how to save the day. Las Vegas Weekly. Retrieved from https://lasvegasweekly.com/intersection/2017/jul/27/the-superhero-foundry-teaches-youto-save-the-day/\#/0

Resnick, M. D., Bearman, P. S., Blum, R. W., Bauman, K. E., Harris, K. M., Jones, J. V., Tabor, J., Beuhring, T. B., Sieving, R. E., Shew, M. L., Ireland, M. T., Bearinger, L. H., \& Udry, J. R. (1997). Protecting adolescents from harm: findings from the National Longitudinal Study on Adolescent Health. Jama, 278, 823-832.

Smith, A. R., Chein, J. \& Steinberg, L. (2013). Impact of socio-emotional context, brain development, and pubertal maturation on adolescent risk-taking. Hormones and behavior, 64(2), 323-332.

Steinberg, L. (2012). Should the science of adolescent brain development inform public policy? Issues in Science and Technology, Spring, 67-78.

Steinberg, L. (2015). The neural underpinnings of adolescent risk-taking: The roles of reward-seeking, impulse control, and peers. Self-regulation in Adolescence, 173-192. 
Steinberg, S. (2017, May 9). Super Ewan helps the homeless in Detroit. The Detroit News.

Retrieved from https://www.detroitnews.com/story/news/local/detroitcity/2017/05/09/ super-ewan-helps-homeless-detroit/101454214/

\section{CONFLICT OF INTEREST}

The authors declare that the research was conducted in the absence of any commercial or financial relationships that could be construed as a potential conflict of interest. 